\title{
Second hip fracture in elderly patients
}

\author{
Yaşlı hastalarda ikinci kalça kırığı \\ O. Şahap Atik, M.D. \\ Department of Orthopedics and Traumatology, Medical Faculty of Gazi University, Ankara, Turkey
}

Osteoporotic fractures are common due to the increase of the average age of the population all over the world. The awareness and knowledge on osteoporosis have increased in the last decade. However, the problem of a second hip fracture has not been emphasized enough. ${ }^{[1]}$

The cumulative incidence of second hip fractures (SHF) was 9\% in the Netherlands. ${ }^{[2]}$ The relatively high risk of sustaining SHF demonstrates the importance of secondary prevention in patients with a prior wrist or vertebral fracture.

In a nationwide population-based longitudinal observational study using the National Health Insurance Research Database in Taiwan, the overall incidence of SHF was $9.18 \%$, and the age-specific mortality increased 1.6- to 2.2-fold in patients with SHF compared with those not having undergone first hip fracture surgery. ${ }^{[3]}$

A meta-analysis indicated that the significant risk factors for SHF were being female (OR, 1.46; 95\% CI, 1.29-1.66), living in institutions (OR, 2.23; 95\% CI, 1.293.83), osteoporosis (Singh index 1-3) (OR, 10.02; 95\% CI, 5.41-18.57), low vision (OR, 2.09; 95\% CI, 1.06-4.12), dementia (OR, 1.89; 95\% CI, 1.47-2.43), Parkinson (OR, 2.90; 95\% CI, 1.41-5.95), cardiac diseases (OR, 1.32; $95 \% \mathrm{CI}, 1.02-1.70)$, and respiratory disease (OR, 1.97; $95 \%$ CI, 1.16-3.32) ${ }^{[4]}$
In another systematic review and meta-analysis of models of care for the secondary prevention of osteoporotic fractures, there were four general models of care which included type A: identification, assessment and treatment of patients as part of the service; type B: similar to A, without treatment initiation; type C: alerting patients plus primary care physicians; and type D: patient education only. Types $A$ and $B$ were cost-effective, although definition of cost-effectiveness varied between studies. ${ }^{[5]}$

\section{REFERENCES}

1. Moradi R, Atik OS. Are orthopedic surgeons more aware of medical treatment of osteoporotic fractures in the last decade? [Article in Turkish] Eklem Hastalik Cerrahisi 2014;25:80-4.

2. Burgers PT, Zielinski SM, Mailuhu AK, Heetveld MJ, Verhofstad $\mathrm{MH}$, Roukema GR, et al. Cumulative incidence and treatment of non-simultaneous bilateral femoral neck fractures in a cohort of one thousand two hundred and fifty patients. Int Orthop 2014;38:2335-42.

3. Shen SH, Huang KC, Tsai YH, Yang TY, Lee MS, Ueng SW, et al. Risk analysis for second hip fracture in patients after hip fracture surgery: a nationwide population-based study. J Am Med Dir Assoc 2014;15:725-31.

4. Zhu Y, Chen W, Sun T, Zhang Q, Cheng J, Zhang Y. Metaanalysis of risk factors for the second hip fracture (SHF) in elderly patients. Arch Gerontol Geriatr 2014;59:1-6.

5. Ganda K, Puech M, Chen JS, Speerin R, Bleasel J, Center $\mathrm{JR}$, et al. Models of care for the secondary prevention of osteoporotic fractures: a systematic review and metaanalysis. Osteoporos Int 2013;24:393-406.

\footnotetext{
- Correspondence: O. Şahap Atik, M.D. Gazi Üniversitesi Tıp Fakültesi Ortopedi ve Travmatoloji Anabilim Dalı, 06500 Beşevler, Ankara, Turkey. Tel: +90 312 - 2025528 Fax: +90 312 - 2129008 e-mail: satikmd@gmail.com
} 